Supporting Information for

\title{
Aurone Derivative Revealing the Metabolism of Lipid Droplets and Monitoring Oxidative Stress in Living Cells
}

\author{
Kangnan Wang, ${ }^{\dagger}{ }^{\ddagger}$ Shuyue Ma, ${ }^{\dagger}$ Yanyan Ma, ${ }^{\dagger}$ Yuping Zhao, ${ }^{\dagger}$ Miaomiao Xing, ${ }^{\dagger}$ \\ Liyu Zhou, ${ }^{\dagger}$ Duxia Cao, ${ }^{*},{ }^{\dagger}$ Weiying Lin,,${ }^{*} \dagger$
}

${ }^{\dagger}$ School of Materials Science and Engineering, Institute of Fluorescent Probes for Biological Imaging, University of Jinan, Jinan, 250022, Shandong, China Email: duxiacao@ujn.edu.cn (D. Cao); weiyinglin2013@163.com (W. Lin).

* Shunde Hospital, Southern Medical University (The First People's Hospital of Shunde), Foshan, 528308, Guangdong, China 


\section{Table of Contents}

Experiment details

Figure S1. UV-vis absorption spectra of DMMB in organic solvents with varying polarity. S4

Figure S2. UV-vis absorption and fluorescence spectra of ECMB and PMB in various organic solvents. S4

Table S1. Photophysical properties of the probes in various solvents S5

Figure S3. Theoretical calculation of the probes by DFT. .S6

Figure S4. The pH stability and selectivity of the probes .S6

Figure S5. Viability of HeLa/A549 cells treated with various concentrations of probes. S6

Figure S6. 3D fluorescence images of A549 cells treated with DMMB by OPM and TPM modes. S7

Figure. S7. The LDs confocal images of DMMB with Syto 59 in living cells.

Figure S8. Photobleaching test of DMMB/ECMB/PMB and BODIPY with different scanning times. S8

Figure S9. DMMB used to detect changes in cell polarity induced by oxidative stress ..S8 


\section{Experimental details}

Synthesis of the probes. The synthetic routes of the probes are shown in Scheme S1. DMMB, red solid, m.p. 174-175 ${ }^{\circ}{ }^{1} \mathrm{H}$ NMR $\left(\mathrm{CDCl}_{3}, 400 \mathrm{MHz}\right): \delta 3.09$ (s, 6H), $6.87(\mathrm{~d}, J=7.6 \mathrm{~Hz}, 2 \mathrm{H}), 6.91(\mathrm{~s}, 1 \mathrm{H}), 7.20(\mathrm{t}, J=7.6 \mathrm{~Hz}, 1 \mathrm{H}), 7.32(\mathrm{~d}, J=8.0 \mathrm{~Hz}$, $1 \mathrm{H}), 7.62(\mathrm{t}, J=8.0 \mathrm{~Hz}, 1 \mathrm{H}), 7.81(\mathrm{~d}, J=7.6 \mathrm{~Hz}, 1 \mathrm{H}), 7.87(\mathrm{~d}, J=9.2 \mathrm{~Hz}, 2 \mathrm{H})$. ECMB, yellow solid, m.p. 177-179 ${ }^{\circ}{ }^{1} \mathrm{H} \mathrm{NMR}\left(\mathrm{CDCl}_{3}, 400 \mathrm{MHz}\right): \delta 1.46$ (t, $J=7.2$ $\mathrm{Hz}, 3 \mathrm{H}), 4.37(\mathrm{q}, J=7.2 \mathrm{~Hz}, 2 \mathrm{H}), 7.15(\mathrm{~s}, 1 \mathrm{H}), 7.22(\mathrm{t}, J=7.2 \mathrm{~Hz}, 1 \mathrm{H}), 7.30(\mathrm{t}, J=$ $7.2 \mathrm{~Hz}, 1 \mathrm{H}), 7.39-7.46(\mathrm{~m}, 3 \mathrm{H}), 7.51(\mathrm{t}, J=7.2 \mathrm{~Hz}, 1 \mathrm{H}), 7.65(\mathrm{t}, J=7.2 \mathrm{~Hz}, 1 \mathrm{H}), 7.83$ $(\mathrm{d}, J=7.6 \mathrm{~Hz}, 1 \mathrm{H}), 8.06(\mathrm{~d}, J=8.4 \mathrm{~Hz}, 1 \mathrm{H}), 8.18(\mathrm{~d}, J=7.6 \mathrm{~Hz}, 1 \mathrm{H}), 8.64(\mathrm{~s}, 1 \mathrm{H})$. PMB, orange solid, m.p. 224-226 ${ }^{\circ}{ }^{1} \mathrm{H} \mathrm{NMR}\left(\mathrm{CDCl}_{3}, 400 \mathrm{MHz}\right): \delta 7.24(\mathrm{t}, J=7.6 \mathrm{~Hz}$, $1 \mathrm{H}), 7.38(\mathrm{~d}, J=8.0 \mathrm{~Hz}, 1 \mathrm{H}), 7.66(\mathrm{t}, J=7.2 \mathrm{~Hz}, 1 \mathrm{H}), 7.86(\mathrm{~d}, J=7.6 \mathrm{~Hz}, 1 \mathrm{H}), 7.96$ $(\mathrm{s}, 1 \mathrm{H}), 8.01(\mathrm{t}, J=7.6 \mathrm{~Hz}, 1 \mathrm{H}), 8.04(\mathrm{~d}, J=9.6 \mathrm{~Hz}, 1 \mathrm{H}), 8.11(\mathrm{~d}, J=8.8 \mathrm{~Hz}, 1 \mathrm{H})$, 8.17-8.23 (m, 4H), $8.56(\mathrm{~d}, J=9.2 \mathrm{~Hz}, 1 \mathrm{H}), 8.93(\mathrm{~d}, J=8.4 \mathrm{~Hz}, 1 \mathrm{H})$.
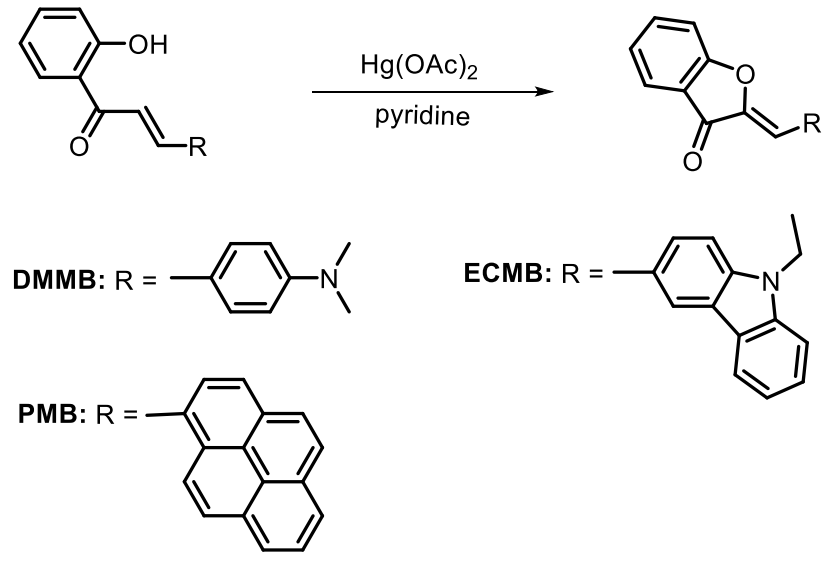

Scheme S1. Synthetic routes of the probes.

Lipophilicity test. The lipophilicity of the probes was measured by the determination of $\log \mathrm{P}_{\mathrm{o} / \mathrm{w}}$, which was referred to as the $n$-octanol/water partition coefficient, following a reported procedure (Phys. Chem. Chem. Phys. 2016, 18, 24185-24197).

$$
\log P_{o / w}=\log _{10}\left(A_{o} / A_{w}\right)
$$

(where $P_{o / w}$ is the $n$-octanol/water partition coefficient, $A_{o}$ and $A_{w}$ are the absorbance of the probes at the absorption peaks in $n$-octanol and water phase, respectively)

Spectral measurement instruments. UV-vis absorption and fluorescence spectra were carried out on a Shimadzu UV2550 spectrophotometer and a Horiba Fluoromax-4 fluorescence spectrometer, respectively.

Materials for cell imaging. Phosphate buffered saline (PBS, Sigma Aldrich). 3-(4,5-dimethylthiazol-2-yl)-2,5-diphenyltetrazolium bromide (MTT, Sigma Aldrich). BODIPY 493/503 (BODIPY), Mito Tracker Red (MTR), Mito Tracker Deep Red (MTDR), Syto 59 and Hank's balanced salt solution (HBSS) were all obtained from Thermo Fisher Scientific. Oleic acid was bought from J\&K Scientific Ltd. 


\section{Supporting Figures and Tables}

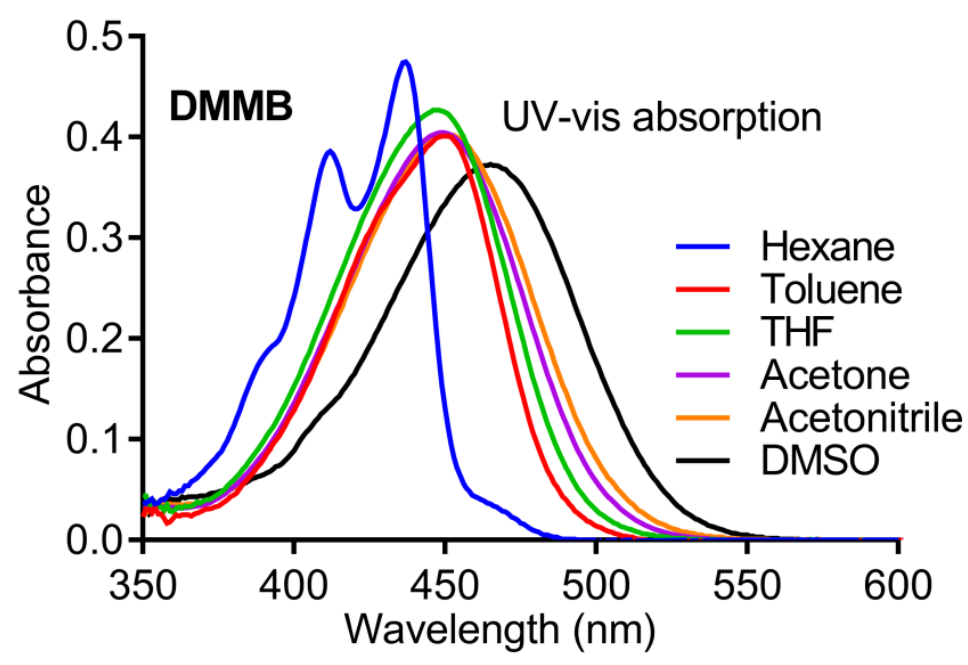

Figure S1. UV-vis absorption spectra of DMMB $(10 \mu \mathrm{M})$ in organic solvents with varying polarity.
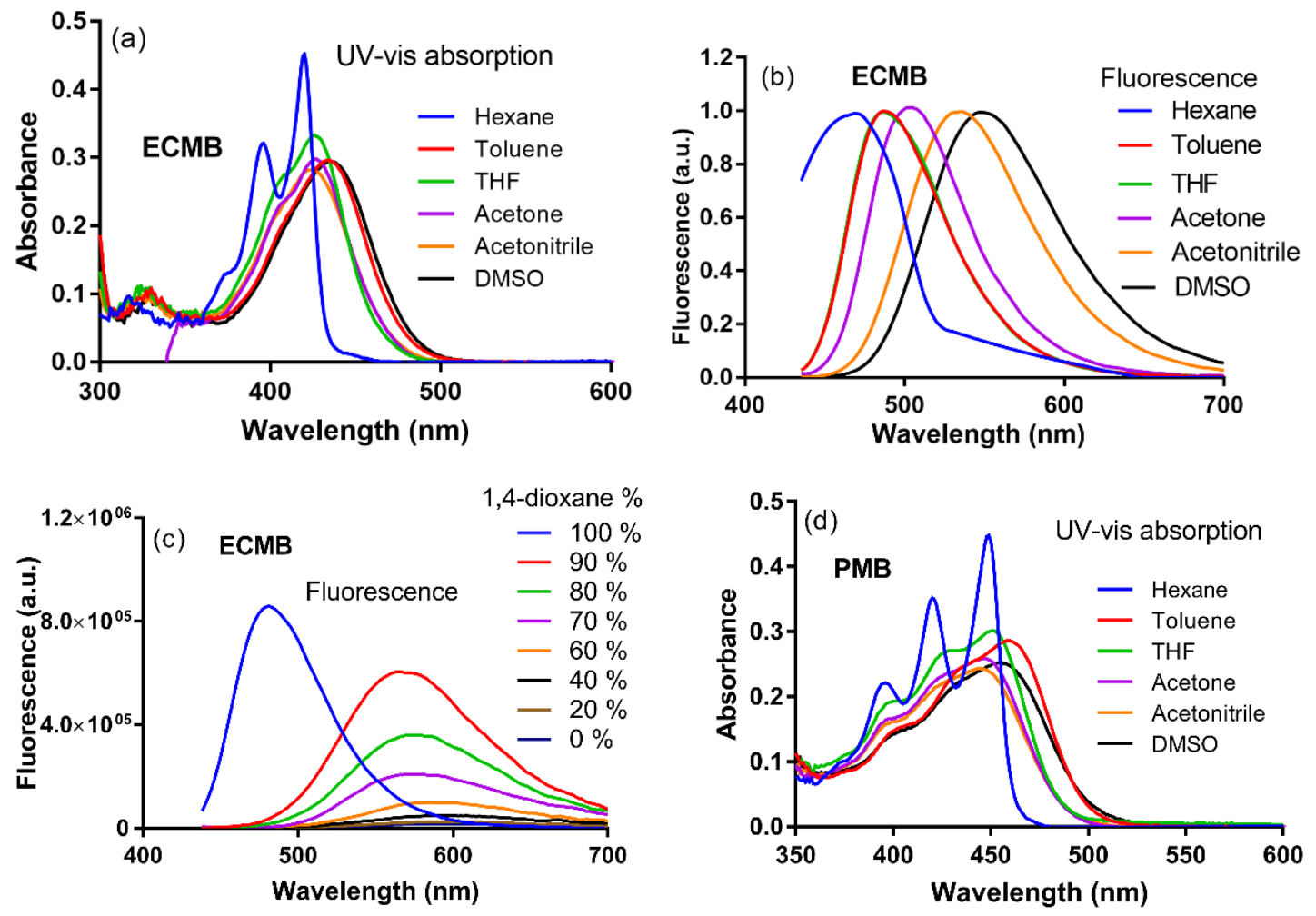

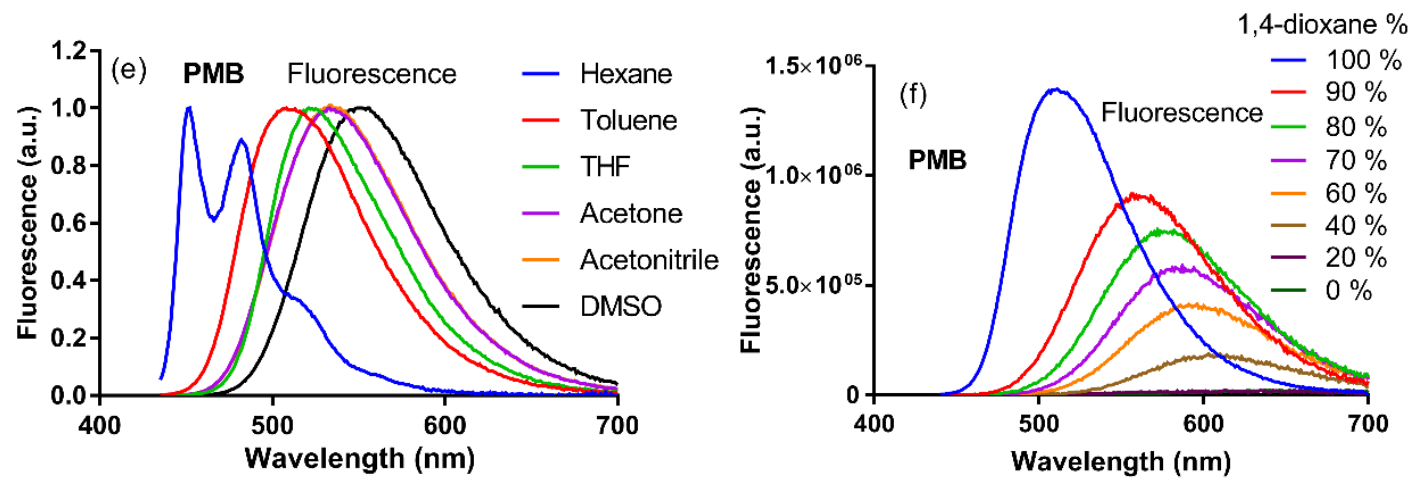

Figure S2. UV-vis absorption ((a), (d)) and normalized fluorescence ((b), (e)) spectra of ECMB and PMB in the organic solvents with varying polarity. Fluorescence spectra of ECMB and PMB in the mixture of water and 1, 4-dioxane with different proportions. ( $\lambda_{\mathrm{ex}}=405 \mathrm{~nm}$, (c), (f))

Table S1 Photophysical properties of the probes in various solvents.

\begin{tabular}{lllll}
\hline Compound & Solvents & $\lambda_{\max }$ abs $(\mathrm{nm})$ & $\varepsilon\left(10^{4} \mathrm{M}^{-1} \mathrm{~cm}^{-1}\right)$ & $\lambda_{\max }^{\text {fluo }}(\mathrm{nm})$ \\
\hline \multirow{4}{*}{ DMMB } & Hexane & 412,437 & $3.85,4.75$ & 450,480 \\
& Toluene & 450 & 4.02 & 501 \\
& THF & 448 & 4.29 & 532 \\
& Acetone & 450 & 4.06 & 557 \\
& Acetonitrile & 452 & 4.03 & 570 \\
& DMSO & 465 & 3.71 & 592 \\
\hline \multirow{4}{*}{ ECMB } & Hexane & 396,420 & $3.20,4.48$ & 469 \\
& Toluene & 435 & 2.97 & 488 \\
& THF & 426 & 3.34 & 488 \\
& Acetone & 427 & 2.97 & 503 \\
& Acetonitrile & 423 & 2.81 & 535 \\
& DMSO & 437 & 2.92 & 549 \\
\hline \multirow{4}{*}{ PMB } & Hexane & $396,420,449$ & $2.21,3.49,4.46$ & 451,482 \\
& Toluene & 460 & 2.87 & 510 \\
& THF & $398,427,451$ & $1.92,2.69,3.02$ & 523 \\
& Acetone & 446 & 2.58 & 534 \\
& Acetonitrile & 444 & 2.43 & 535 \\
& DMSO & 457 & 2.51 & 552 \\
\hline
\end{tabular}




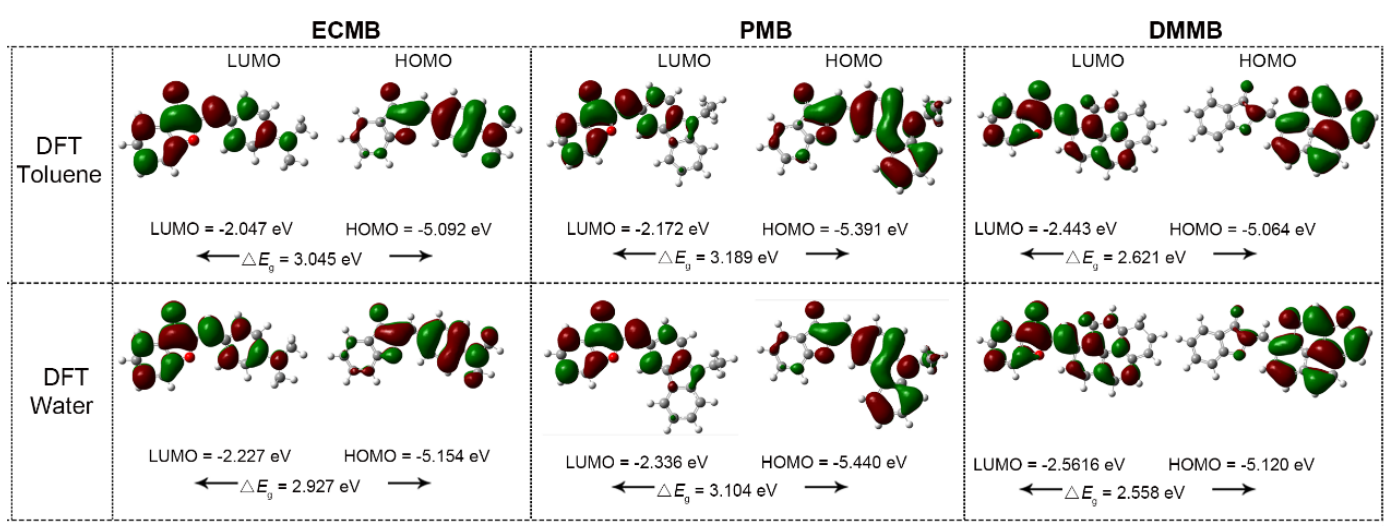

Figure S3. Theoretical calculation of the probes by DFT.
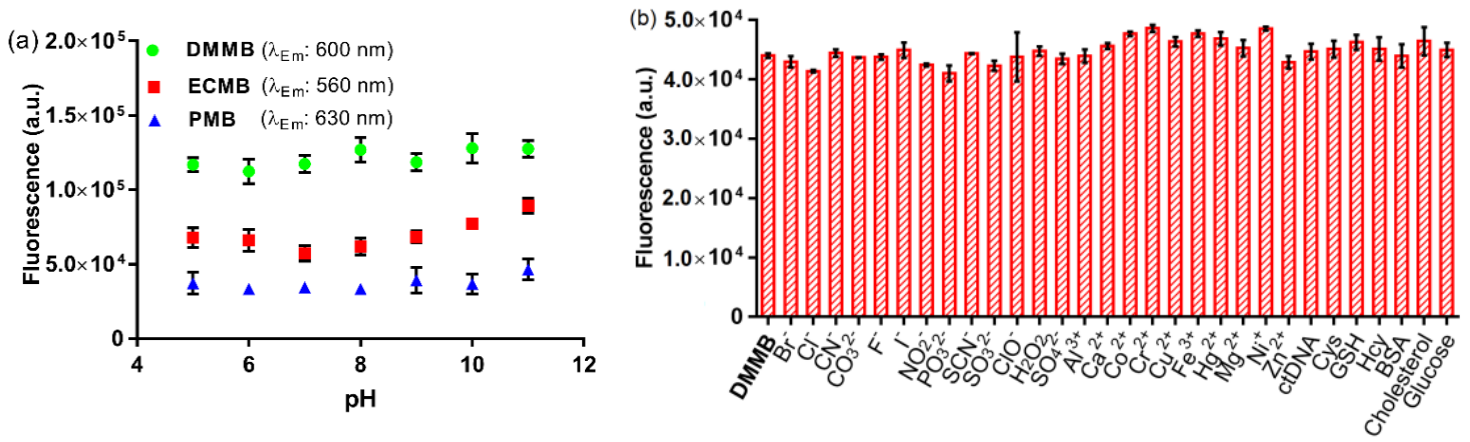

Figure S4. (a) The pH stability of the probes. (b) The selectivity of DMMB for other species ( $\mathrm{Br}^{-}$, $\mathrm{Cl}^{-}, \mathrm{CN}^{-}, \mathrm{CO}_{3}{ }^{2-}, \mathrm{F}, \mathrm{I}^{-}, \mathrm{NO}_{2}{ }^{-}, \mathrm{PO}_{3}{ }^{2-}, \mathrm{SCN}^{-}, \mathrm{SO}_{3}{ }^{2-}, \mathrm{ClO}^{-}, \mathrm{H}_{2} \mathrm{O}_{2}, \mathrm{SO}_{4}{ }^{2-}, \mathrm{Al}^{3+}, \mathrm{Ca}^{2+}, \mathrm{Co}^{2+}, \mathrm{Cr}^{2+}, \mathrm{Cu}^{2+}$, $\mathrm{Fe}^{3+}, \mathrm{Hg}^{2+}, \mathrm{Mg}^{2+}, \mathrm{Ni}^{+}, \mathrm{Zn}^{2+}, \mathrm{ctDNA}, \mathrm{Cys}, \mathrm{GSH}, \mathrm{Hcy}$, bovine serum albumin (BSA), Cholesterol, Glucose).
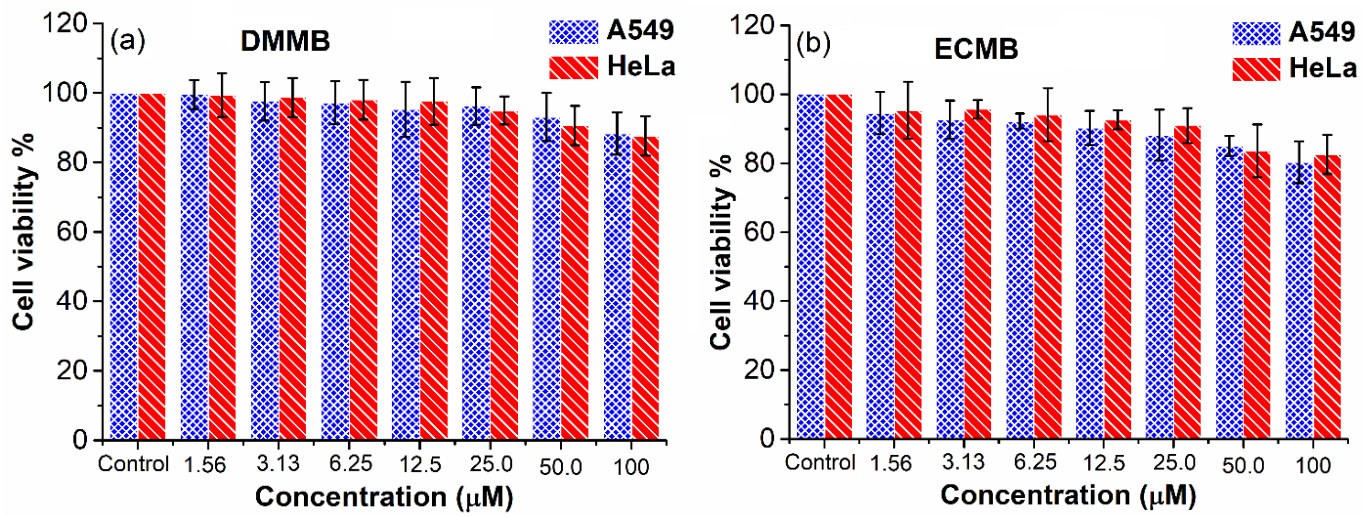


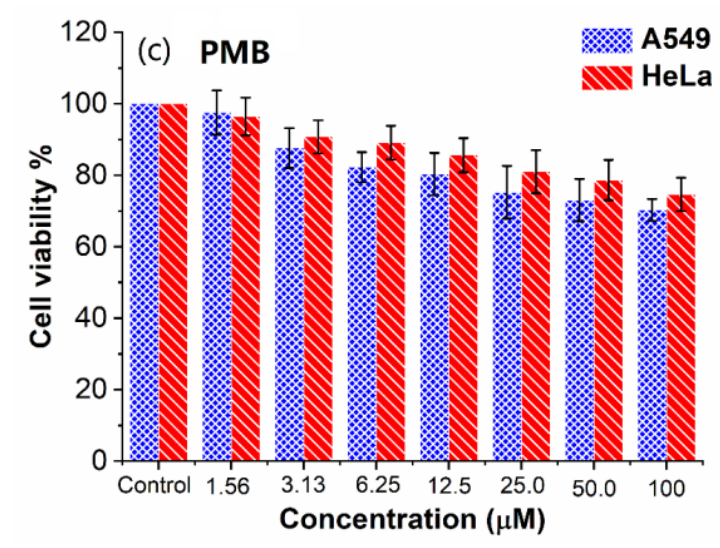

Figure S5. Viability of HeLa/A549 cells treated with the various concentrations of probes for 24 h.

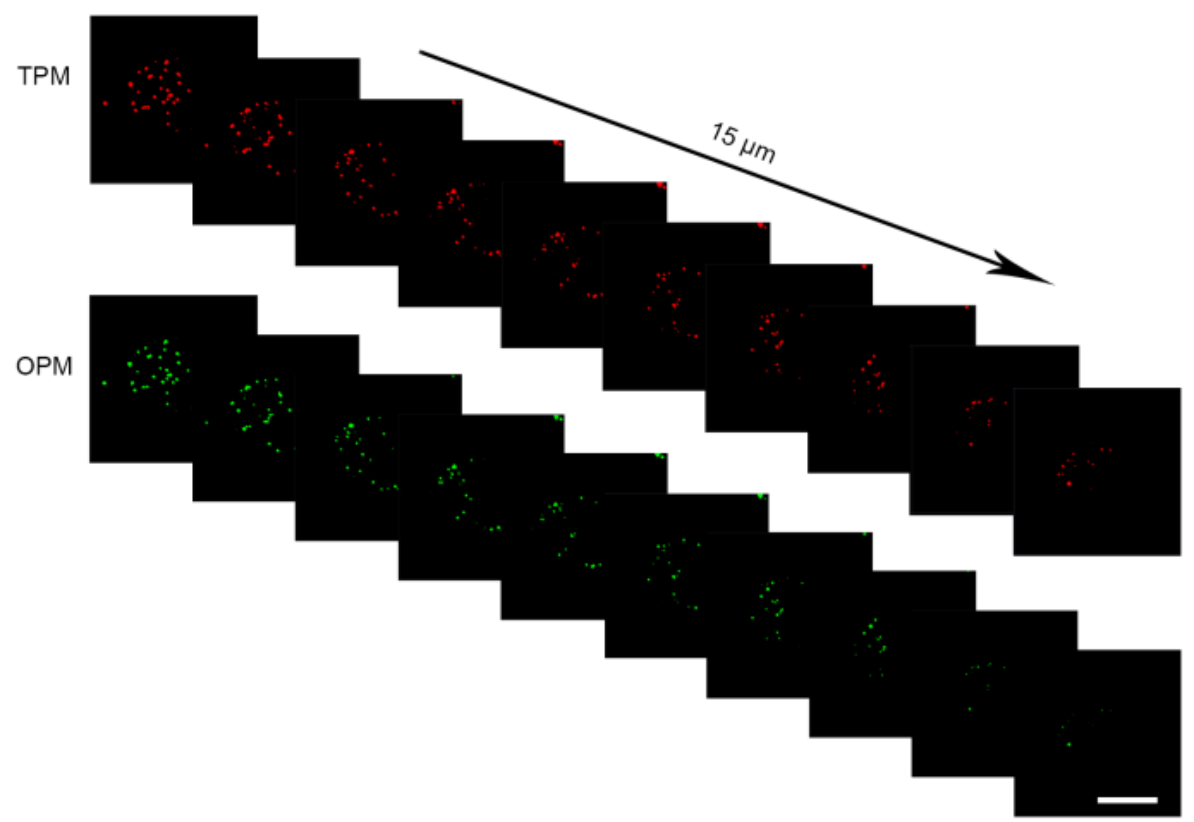

Figure S6. 3D fluorescence images of A549 cells treated with DMMB $(20 \mu \mathrm{M})$ by one- (OPM) and two-photon (TPM) modes. Scale bar: $20 \mu \mathrm{m}$.
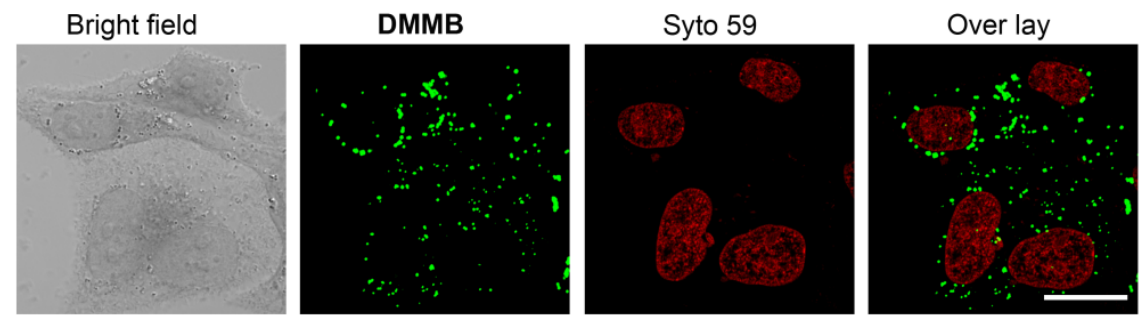

Figure. S7. The LDs confocal images of DMMB $(20 \mu \mathrm{M})$ with Syto $59\left(\lambda_{\mathrm{ex} / \mathrm{em}}=633 / 650 \pm 10 \mathrm{~nm}\right)$ in living cells. Scale bar: $20 \mu \mathrm{m}$. 

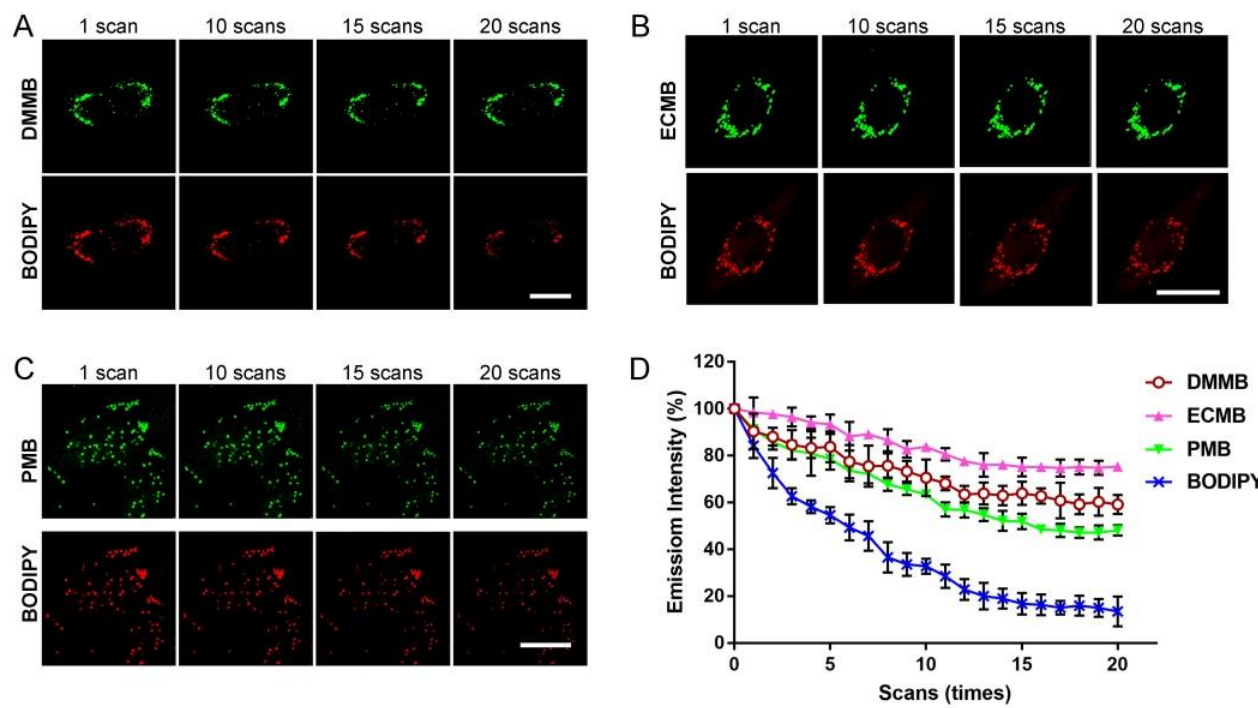

Figure S8. (A-C) The confocal images of DMMB/ECMB/PMB and BODIPY in A549 cells with different scanning times (1-20) Scale bar: $20 \mu \mathrm{m}$. (D) The emission intensities change of integral area for DMMB/ECMB/PMB and BODIPY with scan times.

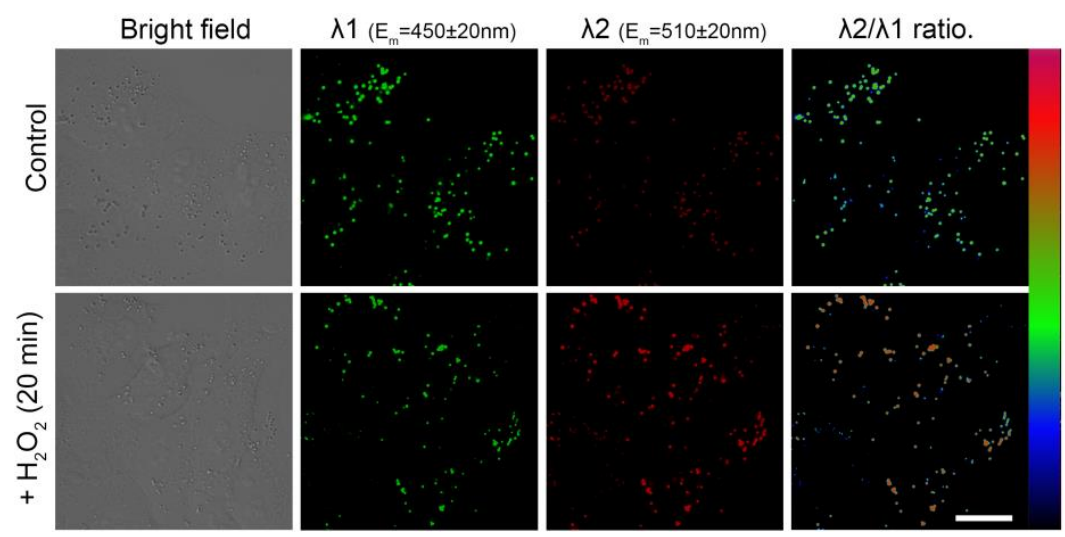

Figure S9. The confocal images of DMMB-stained HeLa cells treated with $10 \mathrm{mM} \mathrm{H}_{2} \mathrm{O}_{2}$ for 20 $\min . \lambda 1=450 \pm 20 \mathrm{~nm}$ and $\lambda 2=510 \pm 20 \mathrm{~nm}$ were used to split the emission into the two channels. $\lambda_{\mathrm{ex}}=405 \mathrm{~nm}$. Scale bar: $20 \mu \mathrm{m}$. 